\title{
38. GEOCHEMISTRY AND PETROLOGY OF ORGANIC MATTER IN MIOCENE TO QUATERNARY DEEP SEA SEDIMENTS FROM THE JAPAN SEA (SITES 798 AND 799) ${ }^{1}$
}

\author{
E. Lichtfouse, ${ }^{2}$ R. Littke, ${ }^{2}$ U. Disko, ${ }^{2}$ H. Willsch, ${ }^{2}$ J. Rullkötter,,${ }^{2,3}$ and R. Stein ${ }^{4}$
}

\begin{abstract}
Miocene to Quaternary sediments from the Oki Ridge (Site 798) and the Kita-Yamato Trough (Site 799) in the Japan Sea contain organic carbon ranging from about $0.6 \%$ in light-colored layers to almost $6 \%$ in dark layers. The organic matter consists of a variable mixture of marine and terrigenous contributions, the ratio of which is not correlated to the total organic carbon content. Marine organic particles clearly dominate in the deeper section of Hole 799B. The extractable bitumen is strongly dominated by long-chain alkenones from microalgae in the shallower sediments, whereas bishomohopanoic acid $\left(\mathrm{C}_{32}\right)$ of eubacterial origin is the single most abundant compound in deeper samples. Normal alkanes and straight-chain carboxylic acids, both of which show a bimodal distribution with odd and even carbon-number predominance, respectively, are two other groups of compounds which are important constituents of the extracts. The deepest samples at Site 799 contain a considerable amount of short-chain components, which probably migrated upward from thermally more altered deeper sediments.
\end{abstract}

\section{INTRODUCTION}

The Japan Sea is a back-arc basin which began to form by continental rifting in middle Tertiary time (estimated maximum age 26 m.y.). It was fully developed by the middle Miocene, and is now in the initial stage of compressive deformation and collapse. During this period of time, $1500-3000 \mathrm{~m}$ of sediments were rapidly accumulated (average rate $120 \mathrm{~m} / \mathrm{m} . \mathrm{y}$.) in relatively deep, cold and well-oxygenated waters. A typical sequence includes an upper well-stratified and highly reflective unit composed of upper Pliocene to Holocene siliciclastic sands, silts and/or overlying clays, and a seismically transparent to moderately reflective unit of lower Pliocene to Miocene hemipelagic diatomaceous clays and other mud rocks (Ingle, Suyehiro, von Breymann, et al., 1990).

We report here a preliminary study on the organic matter occurring in sediments from Oki Ridge (Site 798) and Kita-Yamato Trough (Site 799) (Fig. 1). The sedimentary sequences consist predominantly of biosiliceous and diagenetically altered siliceous sediments (Ingle, Suyehiro, von Breymann, et al., 1990). On Oki Ridge, $518 \mathrm{~m}$ of largely pelagic and hemipelagic sediments were cored; they range from late early Pliocene to Holocene in age. In Kita-Yamato Trough, $1084 \mathrm{~m}$ of sediment range in age from early(?) Miocene to the Holocene. Basal lower Miocene sediments from Kita-Yamato Trough include coarse turbidite sands rich in plant debris and other evidence of transport from nearby shallow-water and terrestrial environments during the early rifting phase.

Shipboard measurements (Ingle, Suyehiro, von Breymann, et al., 1990) showed that these sediments are enriched in organic carbon relative to open marine sediments (total organic carbon $[\mathrm{TOC}]=1 \%-6 \%$ ), suggesting a high surface productivity or enhanced preservation in suboxic bottom water by rapid burial in turbidites. According to shipboard results on Rock-Eval pyrolysis and $\mathrm{C} / \mathrm{N}$ ratios (around 10), the organic matter is mainly of marine origin (type II) with some terrigenous contribution (type III). A typical feature is the presence of dark/light cycles corresponding to organic-matter-rich/poor sediments.

${ }^{1}$ Pisciotto, K. A., Ingle, J. C., Jr., von Breymann, M. T., Barron, J., et al., 1992. Proc. ODP, Sci. Results, 127/128, Pt. 1: College Station, TX (Ocean Drilling Program).

2 Institut für Erdöl und Organische Geochemie, Forschungszentrum Jülich GmbH (KFA), Postfach 1913, D-5170 Jülich 1, Federal Republic of Germany.

${ }^{3}$ Present address: Institut für Chemie und Biologie des Meeres (ICBM), Universităt Oldenburg, D-2900 Oldenburg, Federal Republic of Germany.

${ }^{4}$ Alfred-Wegener-Institut für Polar- und Meeresforschung. Columbusstrasse, D-2850 Bremerhaven, Federal Republic of Germany.
Molecular fossils have been widely used to give more specific information concerning the source and the maturity of organic matter in sediments. We therefore report the study of the distribution patterns of organic substances occurring in sediments from Oki Ridge and KitaYamato Trough in addition to bulk organic matter characteristics.

\section{SAMPLES AND METHODS}

Sediment samples were received frozen and after thawing were dried at $40^{\circ} \mathrm{C}$. Whole-rock aliquots were set aside for kerogen microscopy, and the remainder was ground in a disc mill. Total carbon and organic carbon (TOC) were determined by combustion in a LECO IR-112 carbon analyzer. The latter measurement was performed after treatment of the samples with hydrochloric acid to remove carbonates. Inorganic carbon contents were calculated by difference and converted to percent calcium carbonate $\left(\mathrm{CaCO}_{3}\right)$ on the assumption that this was the sole carbonate species. Rock-Eval pyrolysis was performed using a Rock-Eval II instrument (Girdel). Hydrogen Index (HI) and Oxygen Index (OI) values were determined from flame ionization detector (FID) and thermal conductivity detector responses, they are expressed as mg hydrocarbon-type material per $\mathrm{g}$ TOC and $\mathrm{CO}_{2}$ per g TOC, respectively.

For microscopic studies, nine whole-rock samples were embedded in a resin in an orientation perpendicular to the bedding, then ground and polished. Maceral abundances were determined using point counting, first in reflected white light, then in fluorescence mode on a Zeiss Photomicroscope III with a step-width of $0.33 \mathrm{~mm}$ on parallel lines perpendicular to bedding. Six hundred points per sample were evaluated using the description nomenclature of Stach et al. (1982).

Twelve sediments from Oki Ridge $(41.5-518.1 \mathrm{~m})$ and 22 sediments from Kita-Yamato Trough (47.7-1081.9 m) were dried, extracted by flow-blending (Radke et al., 1978) with dichloromethane-methanol (99:1), and filtered. The filtrate was concentrated under reduced pressure and treated with an excess of diazomethane in diethyl ether, then with bis(trimethylsilyl) trifluoroacetamide-trimethylchlorosilane (BSTFA-TMCS, 99:1), warmed for $1 \mathrm{hr}$ at $40^{\circ} \mathrm{C}$ and concentrated to near dryness under nitrogen.

The derivatized extracts in ethyl acetate were analyzed by gas chromatography (GC) and gas chromatography-mass spectrometry (GC-MS). GC conditions: Varian 3700 analyzer, split injection (1/3), injector temperature $300^{\circ} \mathrm{C}$, fused silica capillary column $(25 \mathrm{~m}$, $0.32 \mathrm{~mm}$ i.d. $)$, Ultra- 1 phase $(0.52 \mu \mathrm{m}$ film thickness $)$, temperature program: $120^{\circ} \mathrm{C}(2 \mathrm{~min}), 120^{\circ}-320^{\circ} \mathrm{C}(3 \% \mathrm{~min}), 320^{\circ} \mathrm{C}(60 \mathrm{~min})$, helium flow: $3 \mathrm{~mL} / \mathrm{min}$, flame ionization detector. MS conditions: electron impact, $70 \mathrm{eV}$, VG $7070 \mathrm{E}$ mass analyzer (EB type), mass range: 43-800 a.m.u. Compound identification was based on mass 


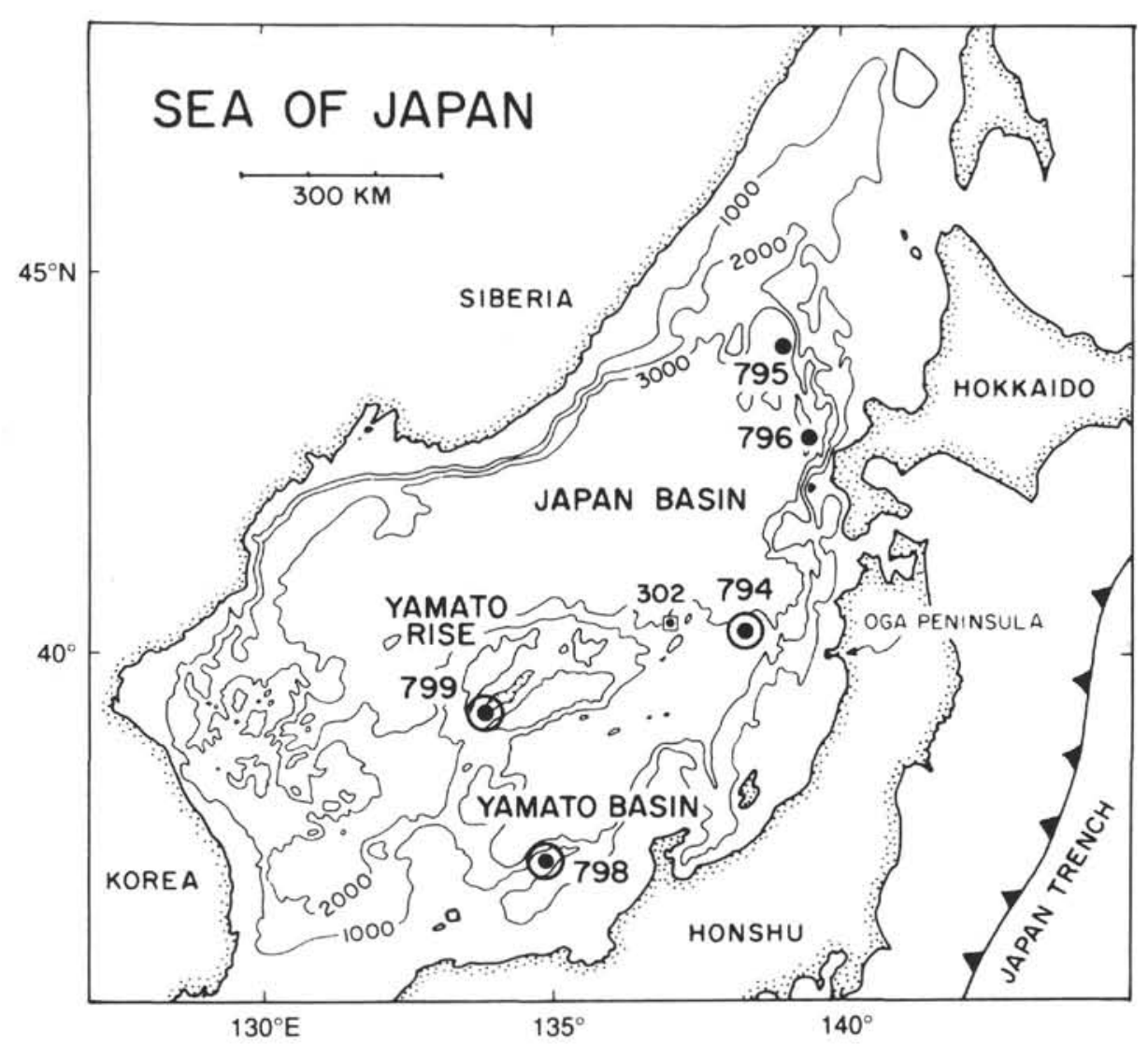

Figure 1. Location map of the Japan Sea showing Site 798 (Oki Ridge) and Site 799 (Kita-Yamato Trough), ODP Leg 128 (Ingle, Suyehiro, von Breymann, et al., 1990). Bathymetry in meters.

spectral information, chromatographic retention times, and comparison with literature data.

\section{RESULTS AND DISCUSSION}

The following paleoenvironmental approach uses a combination of bulk and molecular organic geochemical data to assess the ecologi$\mathrm{cal}$ situation under which organic matter was preserved in the Japan Sea sediments. This fossil organic matter commonly represents less than $0.1 \%$ of the primarily produced biomass (Tissot and Welte, 1984). Furthermore, there may be selective preservation both on the morphological and the molecular level. Relating molecular fossils to precursor organisms is still limited by the restricted knowledge of the lipid composition particular of aquatic organisms. On the other hand, the lipid components amenable by gas chromatography represent only a minor proportion of the total sedimentary organic matter, the main portion being macromolecular material (kerogen) accessible only by bulk chemical or descriptive microscopic methods. These limitations should be kept in mind during the following discussion.

\section{Bulk Parameters}

Total organic carbon (TOC), Hydrogen Index (HI), Oxygen Index (OI), $\mathrm{T}_{\max }$ values, and carbonate percentages are reported in Table 1. Carbonate contents are low $\left(<5 \% \mathrm{CaCO}_{3}\right)$ with few exceptions at Site 799. Most of the sediments are rich in organic carbon, with an average TOC content of $2.5 \%(0.62 \%-5.85 \%$; Table 1$)$. HI and OI values are consistent with a mixed type II-III organic matter (marine-terrigenous), especially in the shallower sediment sections $(<500 \mathrm{~m})$. In the KitaYamato Trough, $\mathrm{HI}$ values increase from about 200 to about $500 \mathrm{mg} / \mathrm{g}$ TOC with increasing depth while the OI values decrease. In agreement with the organic petrology data, this indicates that the proportion of marine organic matter is higher in the deeper section whereas terrigenous organic matter becomes more important in the shallower sediments. $\mathrm{T}_{\max }$ values are variable over a small range (average $413 \pm 11^{\circ} \mathrm{C}$ ) and, together with high S2/S1 ratios, indicate the immature diagenetic stage of the organic matter (Espitalié et al., 1985, 1986).

\section{Organic Petrology}

According to microscopic observations and countings, all samples contain a mixture of marine-derived and terrigenous organic particles. The proportion of marine macerals is positively correlated to HI-values (Fig. 2) as observed in other sedimentary sequences drilled by ODP/DSDP (e.g., Rullkötter, Mukhopadyay, Schaefer, and Welte, 1984; Rullkötter, Mukhopadyay, and Welte, 1984; Stein et al., 1986). Marine particles (alginite and liptodetrinite) clearly predominate in the three deepest samples from Site 799 (Table 2;500-1100 mbsf). In the shallower samples from Site 799, more terrigenous than marine-derived macerals were found. Interestingly, the ratio of terrigenous to marine macerals is almost identical in two adjacent samples from a light/dark cycle at 110 mbsf (799A-13H-3, 22-23 cm, and 799A-13H-3, 26-29 cm), although there are great differences in color, organic carbon content and Hydrogen Index values (Table 1). This observation seems to indicate that the occurrence of the organic-matter-rich dark sediments ("black shales") here is not a simple effect of enhanced plankton productivity and preservation, but that the terrigenous "background" sedimentation also changed during their deposition. Perhaps an increase in supply of terrigenous organic matter and nutrients fostered plankton productivity and organic matter preservation. This would explain the almost identical maceral composition of the two adjacent samples and the higher TOC content of Sample 799A-13H-3, 20-23 cm. It should be noted that the different HI 
Table 1. Organic carbon, carbonate and Rock-Eval pyrolysis data for Oki Ridge (Site 798) and Kita-Yamato Trough (Site 799) sediments.

\begin{tabular}{lrrrrrr}
\hline $\begin{array}{l}\text { Hole, core, section, } \\
\text { interval }(\mathrm{cm})\end{array}$ & $\begin{array}{c}\text { Depth } \\
(\mathrm{mbsf})\end{array}$ & $\begin{array}{c}\text { TOC } \\
(\%)\end{array}$ & $\mathrm{HI}^{\mathrm{a}}$ & $\mathrm{OI}^{\mathrm{a}}$ & $\begin{array}{l}\mathrm{Tmax} \\
\left({ }^{\circ} \mathrm{C}\right)\end{array}$ & $\begin{array}{r}\mathrm{CaCO}_{3} \\
(\%)\end{array}$ \\
\hline 798A- & & & & & & \\
& & & & & & \\
5H-3, 77-83 & 41.50 & 3.82 & 312 & 123 & 414 & 3.5 \\
7H-8, 88-90 & 66.69 & 3.70 & 294 & 109 & 409 & 1.5 \\
11H-2, 93-95 & 96.54 & 4.50 & 336 & 101 & 411 & 2.0 \\
13H-5, 120-125 & 120.63 & 2.74 & 275 & 123 & 413 & 2.0
\end{tabular}

798B-

$\begin{array}{lrrrrrr}14 \mathrm{H}-6,95-100 & 131.38 & 2.82 & 279 & 103 & 421 & 1.4 \\ 22 \mathrm{X}-1,63-68 & 201.26 & 3.22 & 332 & 91 & 413 & 1.1 \\ 27 \mathrm{X}-1,40-44 & 249.42 & 1.82 & 213 & 90 & 411 & 1.5 \\ 35 \mathrm{X}-6,14-16 & 332.65 & 1.77 & 155 & 76 & 410 & 1.5 \\ 40 \mathrm{X}-1,30-34 & 373.52 & 1.90 & 213 & 68 & 415 & 0.9 \\ 47 \mathrm{X}-4,90-94 & 446.22 & 1.16 & 168 & 72 & 409 & 1.2 \\ 53 \mathrm{X}-4,99-101 & 504.20 & 4.41 & 328 & 43 & 426 & 1.3 \\ 54 \mathrm{X}-7,105-108 & 518.07 & 4.32 & 344 & 52 & 416 & 3.8\end{array}$

799A-

$\begin{array}{lrlrrrr}6 \mathrm{H}-6,64-67 & 47.66 & 0.96 & 99 & 140 & 384 & 1.7 \\ 13 \mathrm{H}-3,16-19 & 109.98 & 1.03 & 83 & 182 & 368 & 1.6 \\ 13 \mathrm{H}-3,20-23 & 110.02 & 5.85 & 208 & 111 & 414 & 2.9 \\ 13 \mathrm{H}-3,26-29 & 110.08 & 1.46 & 81 & 150 & 407 & 4.8 \\ 16 \mathrm{H}-7,12-16 & 144.94 & 3.03 & 198 & 217 & 418 & 17.1 \\ 18 \mathrm{H}-3,94-96 & 159.15 & 2.55 & 168 & 106 & 421 & 6.7 \\ 23 \mathrm{X}-3,123-126 & 207.75 & 1.29 & 136 & 296 & 420 & 18.1 \\ 30 \mathrm{X}-3,142-147 & 265.05 & 1.23 & 140 & 98 & 410 & 4.0 \\ 39 \mathrm{X}-1,143-146 & 347.35 & 0.78 & 162 & 154 & 391 & 7.0 \\ 43 \mathrm{X}-3,11-114 & 388.73 & 1.96 & 256 & 82 & 423 & 3.5 \\ 50 \mathrm{X}-5,130-133 & 459.62 & 1.16 & 291 & 54 & 414 & 3.2\end{array}$

799B-

$\begin{array}{lrllrlr}\text { 7R-1, 101-103 } & 500.72 & 3.09 & 337 & 44 & 423 & 5.1 \\ \text { 10R-4, 24-27 } & 533.36 & 2.32 & 303 & 50 & 411 & 2.6 \\ \text { 14R-3, 20-22 } & 570.51 & 4.97 & 380 & 35 & 419 & 4.2 \\ \text { 17R-4, 0-5 } & 600.83 & 2.49 & 374 & 101 & 427 & 20.5 \\ \text { 19R-4, 0-3 } & 620.12 & 2.02 & 384 & 76 & 428 & 9.5 \\ 23 R-2,135-138 & 657.07 & 1.39 & 349 & 59 & 424 & 3.8 \\ 29 R-7,31-35 & 721.13 & 1.95 & 350 & 37 & 416 & \text { b } \\ 47 R-1,23-28 & 885.26 & 3.11 & 513 & 29 & 418 & 4.8 \\ 54 R-2,0-2 & 953.71 & 3.07 & 491 & 50 & 417 & 12.1 \\ 62 R-3,145-150 & 1033.98 & 0.62 & 260 & 47 & 423 & 0.9 \\ 67 R-3,117-120 & 1081.89 & 3.35 & 418 & 10 & 417 & 0.5\end{array}$

${ }^{a} \mathrm{HI}=$ hydrogen index (mg hydrocarbons $/ \mathrm{g} \mathrm{C}_{\mathrm{org}}$ ); $\mathrm{OI}=$ oxygen index $\left(\mathrm{mg} \mathrm{CO}_{2} / \mathrm{g} \mathrm{C}_{\mathrm{org}}\right.$ ).

${ }^{b}$ Off-scale value.

values (Table 1) of the light/dark sediment pair do not prove the existence of different organic matter assemblages, because at the large TOC differences observed, mineral matrix effects may erroneously reduce HI values of sediments with low TOC contents (Katz, 1983). In addition, comparison of TOC data (Table 1) and volume percentages of macerals (Table 2) indicates that slightly fewer macerals than expected were counted in the dark sediment, i.e., a significant proportion (about 20\%) of the organic matter seems to be submicroscopically small (see Littke et al., 1991; Rullkötter et al., 1991). The existence of this submicroscopic organic matter may also account for the different $\mathrm{HI}$ values of the two adjacent samples.

Fewer macerals than expected were also counted in the three samples from Site 798 in which either marine or terrigenous macerals slightly predominate (Table 2 ). The shallowest sample ( $41.50 \mathrm{mbsf}$ ) at this site contains chlorophyllinite, a red fluorescing maceral whose occurrence is restricted to immature sediments (Stach et al., 1982).

Low levels of thermal maturity are indicated for all samples by the occurrence of bright fluorescing liptinite. Quantitative optical maturity parameters were not established due to the low abundance of vitrinite in the deeper sediments (Hole 799B).

\section{Molecular Organic Fossils}

$\mathrm{C}_{37}$ and $\mathrm{C}_{38}$ alkenones with two or three double bonds (molecular ions at $\mathrm{m} / \mathrm{z}=528,530,542,544$ ) were detected as major extractable lipid compounds in shallow sediments (Fig. 3). Their relative concentrations decrease with increasing depth, and they are not detected below $350 \mathrm{~m}$ depth at Sites 798 and 799 .

Long-chain alkenones $\left(\mathrm{C}_{37-39}\right)$ have been detected previously in numerous sediments (mainly young, in exceptional cases up to 45 m.y. in age) at various locations as well as in extant Prymnesiophyceae algae (Marlowe et al., 1984, 1990, and references therein). The precise chemical structures of these compounds isolated from the extant algae Emiliania huxleyi and from marine sediments have recently been elucidated by comparison with synthetic standards (Rechka and Maxwell, 1988). The long-chain alkenones were found to be useful for paleoclimatic reconstruction (Prahl and Wakeham, 1987; Brassell et al., 1986; Jasper and Hayes, 1990). The strong predominance of $\mathrm{C}_{37-38}$ alkenones in Japan Sea sediment extracts (Fig. 3) reflects the contribution of Prymnesiophyceae algae remnants to the organic matter. Their absence below $350 \mathrm{mbsf}$ (Pliocene) may be due to their restricted geological record (Marlowe et al., 1984). However, these compounds may also have been degraded or diagenetically incorporated into the macromolecular kerogen network in deeper sediments.

A C $_{32}$ hopanoid acid $(\mathrm{m} / \mathrm{z}=191,263,369,484)$ is the major compound in the 200-700 mbsf depth range (Fig. 3). As shown by $\mathrm{m} / \mathrm{z}=191$ fragmentograms, it is by far the most abundant hopanoid. Its relative concentration increases from 0 to about $500 \mathrm{mbsf}$ then decreases. Compounds of the hopane family in sediments, particularly those with more than 30 carbon atoms, are indicative of a bacterial source due to the ubiquitous presence of their precursors, i.e., bacteriohopanetetrol $\left(C_{35}\right)$, in eubacteria (Ourisson et al., 1979, 1987). Therefore, the presence of bishomohopanoic acid as major compound in Japan Sea sediments (Fig. 3) should reflect a strong bacterial contribution. The predominance of bishomohopanoic acid could also result, however, from its selective preservation. A predominance of this compound has been reported before for various sediments (van Dorsselaer, 1975; Ensminger, 1977; Schmitter et al., 1978; Ourisson et al., 1979).

Normal alkanes with an odd carbon number predominance extend from $\mathrm{C}_{13}$ to $\mathrm{C}_{33}$ and show a bimodal distribution centered at $\mathrm{C}_{17}$ and $\mathrm{C}_{29}$ as shown by $\mathrm{m} / \mathrm{z}=57$ fragmentograms. A dramatic relative increase of numerous low-molecular-weight compounds $\left(<\mathrm{C}_{18}\right)$ is observed in the deepest sediments from the Kita-Yamato Trough, below about $700 \mathrm{mbsf}$ (Fig. 4). Traces of $\mathrm{C}_{27-29}$ steranes were detected in the deepest samples of the Kita-Yamato Trough by monitoring the $\mathrm{m} / \mathrm{z}=217$ ion current. From their chromatographic pattern and comparison with the literature (Ensminger, 1977; Seifert and Moldowan, 1979; Moldowan et al., 1980), the main members have $5 \alpha(\mathrm{H}), 14 \alpha(\mathrm{H}), 17 \alpha(\mathrm{H})(20 \mathrm{R})$ and $5 \beta(\mathrm{H}), 14 \alpha(\mathrm{H}), 17 \alpha(\mathrm{H})(20 \mathrm{R})$, configurations typical of organic matter in an advanced stage of diagenesis (cf. Rullkötter et al., 1981).

Linear carboxylic acids, extending from $\mathrm{C}_{12}$ to $\mathrm{C}_{32}$ with a strong even predominance, are major compounds of all the sediment samples studied. Their concentration is in the same order of magnitude as that of the $n$ alkanes. Their selective detection was performed by mass fragmentography of the $\mathrm{m} / \mathrm{z}=74$ fragment (Fig. 5). Typical fragmentograms show bimodal distributions centered at $\mathrm{C}_{16}$ and $\mathrm{C}_{26}$.

The presence of $n$-alkanes and $n$-fatty acids at similar relative concentrations and with odd and even carbon number predominance, respectively, as well as their bimodal distributions is in agreement with the postulated relationship between these two classes of substances, i.e., alkanes are derived from acids by decarboxylation (Cooper and Bray, 1963). However, this is not necessarily a diagenetic effect, because formation of alkanes by decarboxylation of fatty acids also happens in the biosynthetic or catabolic pathways of living organisms, particularly higher plants. Thus, this pattern may have been directly inherited from the biosphere. The high relative concen- 


\section{E. LICHTFOUSE ET AL.}

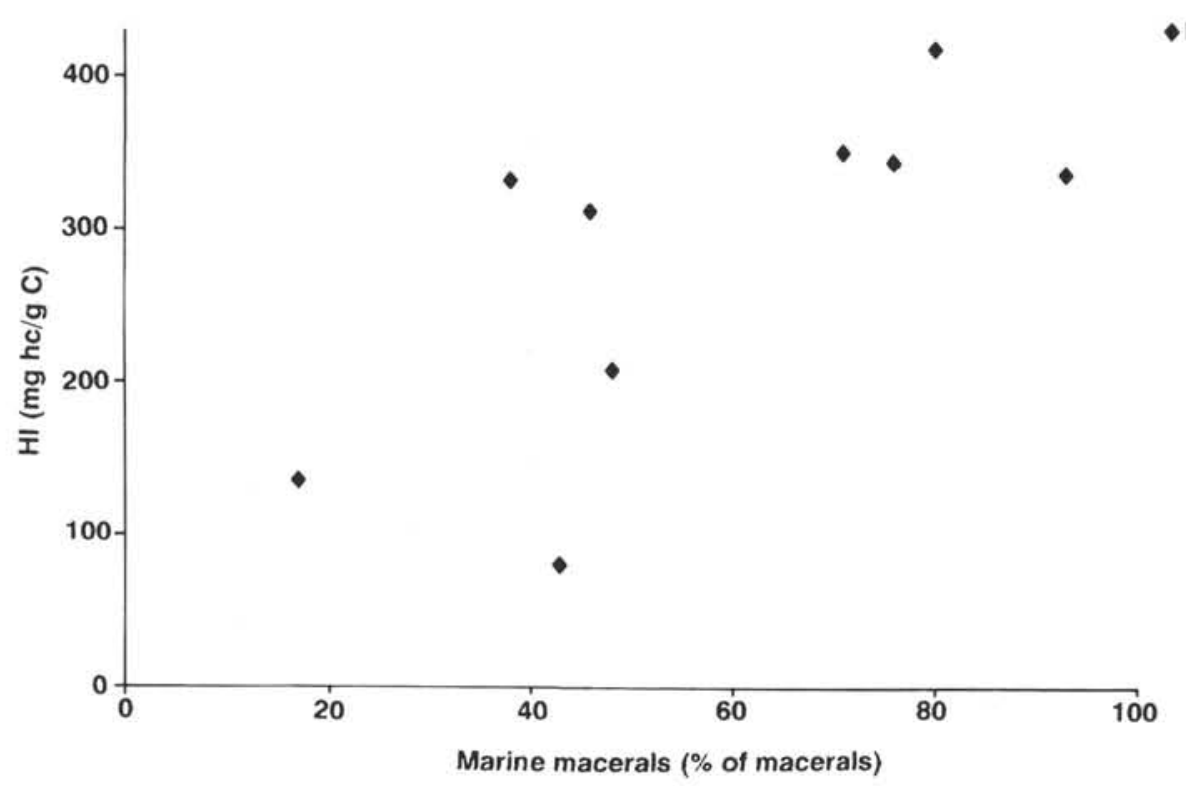

Figure 2. Correlation between Hydrogen Index (HI) and proportion of marine macerals.

Table 2. Whole rock volume percentages of vitrinite, inertinite, sporinite, chlorophyllinite, alginite + liptodetrinite, total macerals, and pyrite in samples from Sites 798 and 799.

\begin{tabular}{|c|c|c|c|c|c|c|c|c|}
\hline Sample & $\begin{array}{l}\text { Depth } \\
\text { (mbsf) }\end{array}$ & $\begin{array}{l}\text { Vitrinite } \\
(\%)\end{array}$ & $\begin{array}{l}\text { Inertinite } \\
(\%)\end{array}$ & $\begin{array}{l}\text { Sporinite } \\
\text { (\%) }\end{array}$ & $\begin{array}{c}\text { Chlorophyllinite } \\
\text { (\%) }\end{array}$ & $\begin{array}{c}\text { Algininite + } \\
\text { liptodetrinite } \\
(\%)\end{array}$ & $\begin{array}{l}\text { Total } \\
\text { macerals } \\
(\%)\end{array}$ & $\begin{array}{c}\text { Pyrite } \\
(\%)\end{array}$ \\
\hline \multicolumn{9}{|l|}{ 798A- } \\
\hline $5 \mathrm{H}-3,77-83 \mathrm{~cm}$ & 41.50 & 0.5 & 0.5 & 0.0 & 0.3 & 1.1 & 2.4 & 2.4 \\
\hline \multicolumn{9}{|l|}{ 798B- } \\
\hline $22 \mathrm{X}-1,63-68 \mathrm{~cm}$ & 201.26 & 0.3 & 1.3 & 0.0 & 0.0 & 1.0 & 2.6 & 2.4 \\
\hline $54 \mathrm{X}-7,105-108 \mathrm{~cm}$ & 518.07 & 0.2 & 0.5 & 0.0 & 0.0 & 2.2 & 2.9 & 4.5 \\
\hline \multicolumn{9}{|l|}{ 799A- } \\
\hline $13 \mathrm{H}-3,20-23 \mathrm{~cm}$ & 110.02 & 1.8 & 1.4 & 0.0 & 0.0 & 2.9 & 6.1 & 5.5 \\
\hline $13 \mathrm{H}-3,26-29 \mathrm{~cm}$ & 110.08 & 0.7 & 0.5 & 0.0 & 0.0 & 0.9 & 2.1 & 3.6 \\
\hline $23 \mathrm{X}-3,123-126 \mathrm{~cm}$ & 207.75 & 0.3 & 0.7 & 0.0 & 0.0 & 0.2 & 1.2 & 1.7 \\
\hline \multicolumn{9}{|l|}{ 799B- } \\
\hline $7 \mathrm{R}-1,101-103 \mathrm{~cm}$ & 500.72 & 0.0 & 0.0 & 0.2 & 0.0 & 2.8 & 3.0 & 5.7 \\
\hline $29 \mathrm{R}-7,31-35 \mathrm{~cm}$ & 721.13 & 0.2 & 0.2 & 0.7 & 0.0 & 2.7 & 3.8 & 5.5 \\
\hline $67 \mathrm{R}-3,117-120 \mathrm{~cm}$ & 1081.89 & 0.0 & 0.9 & 0.0 & 0.0 & 3.6 & 4.5 & 6.8 \\
\hline
\end{tabular}

tration of $n$-fatty acids in all sediment extracts studied and the strong carbon number predominance are indicative of the low maturity of the organic matter. In the deepest samples from Kita-Yamato Trough, the relatively high abundance of low-molecular-weight compounds (Fig. 4) is probably related to the beginning of thermal kerogen cracking (Tissot and Welte, 1984). This led to termination of drilling at this site at a depth of 1084 mbsf. In view of the molecular and organic petrographic indicators suggesting a low level of maturation for the organic matter also in the deepest samples, it appears likely that the thermally generated hydrocarbons have migrated in from deeper horizons.

Dark- and light-colored cycles corresponding to organic-matter-rich and -poor sediments, respectively, have been observed particularly in the upper part of the sections at both sites (Ingle, Suyehiro, von Breymann, et al., 1990). Gas chromatograms of extracts from a dark and a light sediment do not show dramatic differences (Fig. 6): $\mathrm{C}_{37-38}$ alkenones are major compounds in both samples and the types of compounds present do not differ greatly. There is, however, a slightly higher ratio of $n$-alkanes to $n$-fatty acids in the light sediments, possibly owing to the lower stability of the acids to further oxidation, whereas the $\mathrm{C}_{32}$ hopanoid acid concentration is higher in the dark sediment, possibly the result of higher bacterial activity or selective preservation.

The similarity of the chromatograms obtained for dark and light sediments (Fig. 6) again indicates that there was no dramatic change in the type of organic matter, i.e., the nature of contributing organisms accumulated in those sediments.

\section{CONCLUSIONS}

The fossil organic matter record in Miocene to Quaternary sediments from the Oki Ridge (Site 798) and the Kita-Yamato Trough (Site 799) in the Japan Sea is the result of paleoenvironmental conditions of deposition more favorable for the accumulation and preservation of organic matter than under normal open ocean condi- 


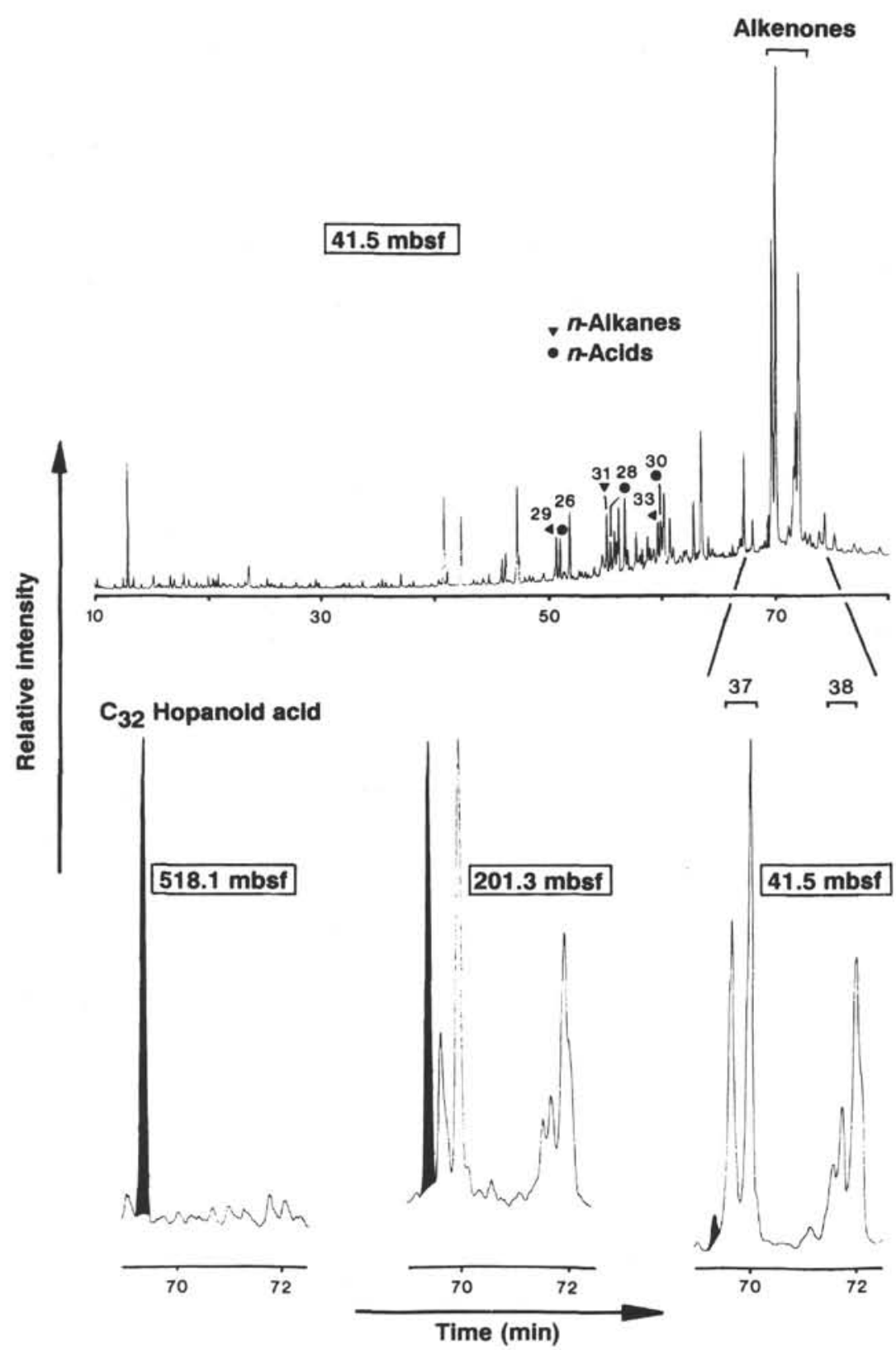

Figure 3. Gas chromatograms of derivatized total extracts from Oki Ridge (Site 798). Note the relative concentration increase of $\mathrm{C}_{32}$ hopanoid acid vs. alkenones with increasing depth on the expanded partial gas chromatogram at the bottom. Carbon numbers are shown on top of $n$-alkane and $n$-fatty acid peaks.

tions. High surface-water productivity, high sedimentation rates (partially enhanced by turbidites), and possibly suboxic (but probably not strictly anoxic) conditions in the water column may have been the most important factors with terrigenous (nutrient) supply playing a modulation role. It is premature, however, to specify the relative importance of these factors in detail and to estimate their interrelationship (see also Stein and Stax, this volume).

The organic matter in all sediments studied is a variable mixture of marine and terrigenous materials as would be expected from the (paleo) geographical setting of the Japan Sea. Pronounced light- and dark-colored sediment cycles represent extremes in the variation of organic carbon contents $(0.62 \%-5.85 \%)$, but surprisingly this does not go along with a drastic change in organic matter type, i.e., the more oxidation resistant terrigenous organic matter is not preferen- tially enriched in the light layers. This is true both for the maceral composition and the distribution of the extractable lipids. We do not have an explanation for this observation.

Long-chain alkenones from microalgae in the shallower sediments ( $<350 \mathrm{mbsf}$ ) and bishomohopanoic acid of eubacterial origin in the deeper layers are the most prominent constituents in the extractable lipids. It is also noteworthy how well the long-chain alkenones are preserved in the bioturbated light-colored sediments with relatively low organic carbon contents. Thus, as observed for the maceral composition, the color distinction is not reflected in the lipid biomarker composition.

Light hydrocarbons, possibly from thermal kerogen breakdown as a result of the high geothermal heat flow in the Japan Sea, are likely to have migrated into the deepest sediments at Site 799 from even deeper horizons, because microscopic and molecular maturity indi- 
cators show that the indigenous organic matter has not reached the hydrocarbon generation level (catagenesis) in the bottom sediments of Hole 799B.

\section{ACKNOWLEDGMENTS}

We are indebted to the Ocean Drilling Program for providing the core samples. We gratefully appreciate the critical reviews of the manuscript by Dr. T. Eglinton (Woods Hole Oceanographic Institution) and Prof. S. A. Macko (University of Virginia, Charlottesville). For technical assistance we thank E. Biermanns, A. Fischer, F. J. Keller, W. Laumer, J. Schnitzler, and M. Sostmann. Financial support by the Deutsche Forschungsgemeinschaft (Grants No. Ru 458/2 and Ste $412 / 3$ ) is gratefully acknowledged.

\section{REFERENCES}

Brassell, S. C., Eglinton, G., Marlowe I. T., Pflaumann, U., and Sarnthein, M., 1986. Molecular stratigraphy: a new tool for climatic assessment. Nature, 320:129-133.

Cooper, J. E., and Bray, E. E., 1963. A postulated role of fatty acids in petroleum formation. Geochim. Cosmochim. Acta, 27:1113-1127.

Ensminger, A., 1977. Evolution de composés polycycliques sédimentaires [Thèse]. Univ. Louis Pasteur, Strasbourg.

Espitalié, J., Deroo, G., and Marquis, F., 1985. La pyrolyse Rock-Eval et ses applications. Rev. Inst. Fr. Pet., 40:563-579; 755-784. 41:73-79.

, 1986. La pyrolyse Rock-Eval et ses applications. Rev. Inst. Fr. Pet.,

Ingle, J. C., Jr., Suyehiro, K., von Breymann, M. T., et al., 1990. Proc. ODP, Init. Repts., 128: College Station, TX (Ocean Drilling Program).

Jasper, J. P., and Hayes, J. M., 1990. A carbon isotope record of $\mathrm{CO}_{2}$ levels during the late Quaternary. Nature, 347:462-464.

Katz, B. J., 1983. Limitations of "Rock-Eval" pyrolysis for typing organic matter. Org. Geochem., 4:195-199.

Littke, R., Rullkötter, J., and Schaefer, R. G., 1991. Organic and carbonate carbon accumulation on Broken Ridge and Ninetyeast Ridge, central Indian Ocean. In Peirce, J., Weissel, J., et al., Proc. ODP, Sci. Results, 121: College Station, TX (Ocean Drilling Program), 467-487.

Marlowe, I. T., Brassell, S. C., Eglinton, G., and Green, J. C. 1984. Long chain unsaturated ketones and esters in living algae and marine sediments. Org. Geochem., 6:135-141.

, 1990. Long chain alkenones and alkyl alkenoates and the fossil coccolith record of marine sediments. Chem. Geol., 88:349-375.

Moldowan, J. M., Seifert, W. K., Haley, M. J., Djerassi, C., 1980. Proof of structure by synthesis of $5 \alpha, 14 \beta, 17 \beta(\mathrm{H})$-cholestane (20R), a major petroleum sterane. Correction of previous assignment. Geochim. Cosmochim. Acta, 44:1613.

Ourisson, G., Albrecht, P., and Rohmer, M., 1979. The hopanoids. Paleochemistry and biochemistry of a group of natural products. Pure Appl. Chem. 51:709-729.
Ourisson, G., Rohmer, M., and Poralla, K., 1987. Microbial lipids betrayed by their fossils. Microbiol. Sci., 4:52-57.

Prahl, F. G., and Wakeham, S. G., 1987. Calibration of an organic thermometer for paleoclimatic assessment. Nature, 330:367-369.

Radke, M., Sittardt, H. G., and Welte, D. H., 1978. Removal of soluble organic matter from rock samples with a flow through extraction cell. Anal. Chem., 50:663-665.

Rechka, J. A., and Maxwell, J.R., 1988. Characterisation of alkenone temperature indicators in sediments and organisms. Org. Geochem., 13:727-734.

Rullkötter, J., Littke, R., Radke, M., Disko, U., Horsfield, B., and Thurow, J., 1991. Petrography and geochemistry of organic matter in Triassic and Cretaceous deep sea sediments from the Wombat and Exmouth Plateaus and nearby abyssal plains off Northwest Australia. In Haq, B. U., von Rad, U., O'Connell, S., et al., Proc. ODP, Sci. Results, 122: College Station, TX (Ocean Drilling Program), 317-333.

Rullkötter, J., Mukhopadhyay, P. K., Schaefer, R. G., and Welte, D. H., 1984. Geochemistry and petrography of organic matter in sediments from Deep Sea Drilling Project Sites 545 and 547, Mazagan Escarpment. In Hinz, K., Winterer, E. L., et al., Init. Repts. DSDP, 79: Washington (U.S. Govt. Printing Office), 775-805.

Rullkötter, J., Mukhopadhyay, P. K., and Welte, D. H., 1984. Geochemistry and petrography of organic matter in sediments from Hole 530A, Angola Basin, and Hole 532, Walvis Ridge, Deep Sea Drilling Project. In Hay, W. W., Sibuet, J.-C., et al., Init. Repts. DSDP, 75: Washington (U.S. Govt. Printing Office), 1069-1087.

Rullkötter, J., von der Dick, H., and Welte D. H., 1981. Organic petrography and extractable hydrocarbons of sediments from the eastern North Pacific Ocean, Deep Sea Drilling Project Leg 63. In Yeats R. S., Haq, B. U., et al., Init. Repts. DSDP, 63: Washington (U.S. Govt. Printing Office), 819-836.

Schmitter, J. M., Arpino, P., and Guiochon, G., 1978. Investigation of highmolecular-weight carboxylic acids in petroleum by different combinations of chromatography (gas and liquid) and mass spectrometry (electron impact and chemical ionization). J. Chrom., 167:149-158.

Seifert, W. K., and Moldowan, J. M., 1979. The effect of biodegradation on steranes and terpanes in crude oils. Geochim. Cosmochim. Acta, 43:111-126.

Stach, E., Mackowsky, M. T., Teichmüller, M., Taylor, G. H., and Chandra, D. (Eds.), 1982. Stach's Textbook of Coal Petrology, Berlin (Gebrüder Borntraeger).

Stein, R., Rullkötter, J., and Welte, D. H., 1986. Accumulation of organic-carbon-rich sediments in the Late Jurassic and Cretaceous Atlantic Ocean-a synthesis. Chem. Geol., 56:1-32.

Tissot, B. P., and Welte, D. H., 1984. Petroleum Formation and Occurrence (2nd ed.): Heidelberg (Springer).

van Dorsselaer, A., 1975. Triterpènes de sédiments [Thèse]. Univ. Louis Pasteur, Strasbourg.

Date of initial receipt: 18 April 1991

Date of acceptance: 19 November 1991

Ms 127/128B-173 


\section{Low molecular}

weight compounds
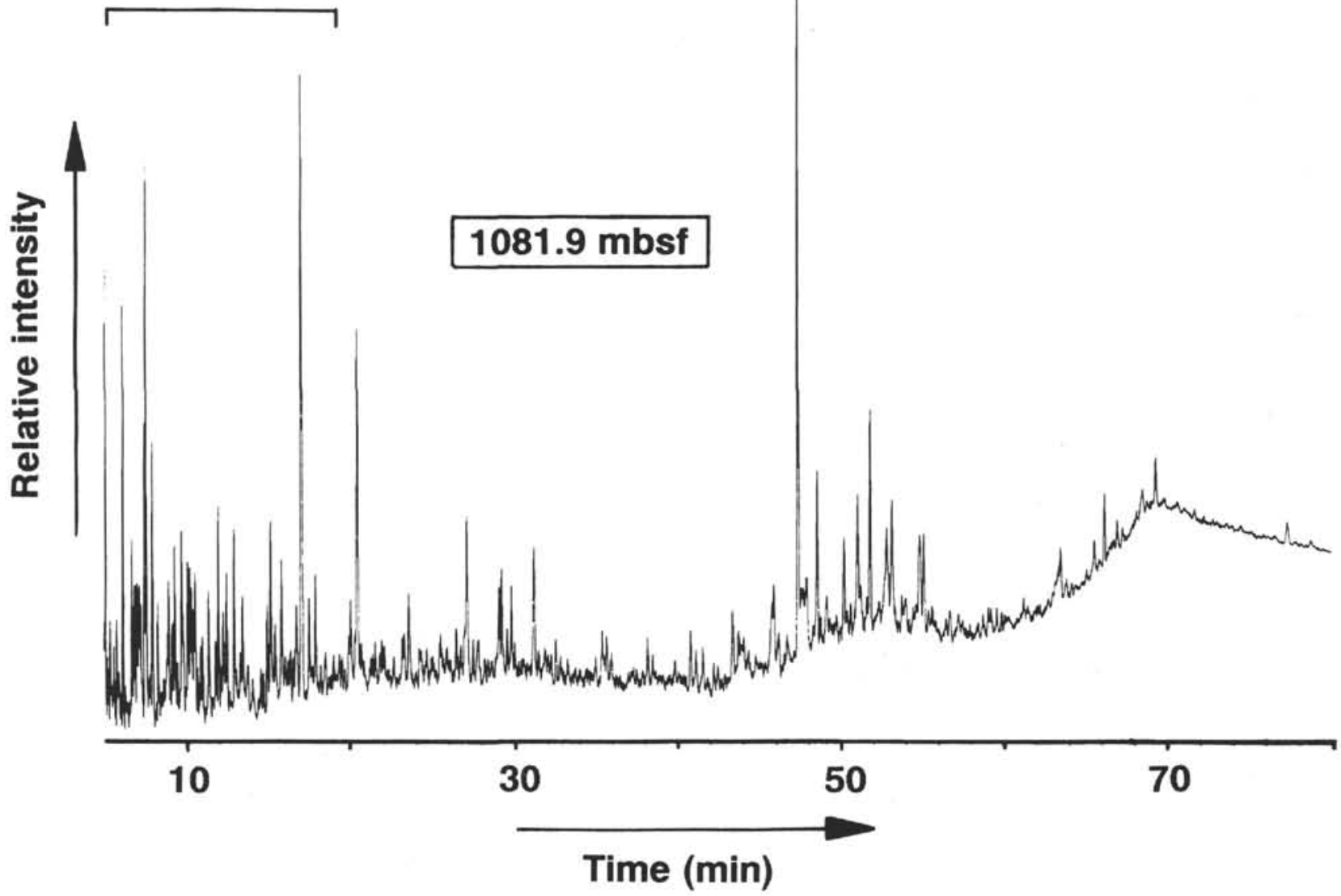

Figure 4. Gas chromatogram of the derivatized total extract from Kita-Yamato Trough (Site 799), depth 1081.9 mbsf. Note the abundance and high relative concentration of low-molecular-weight compounds. 


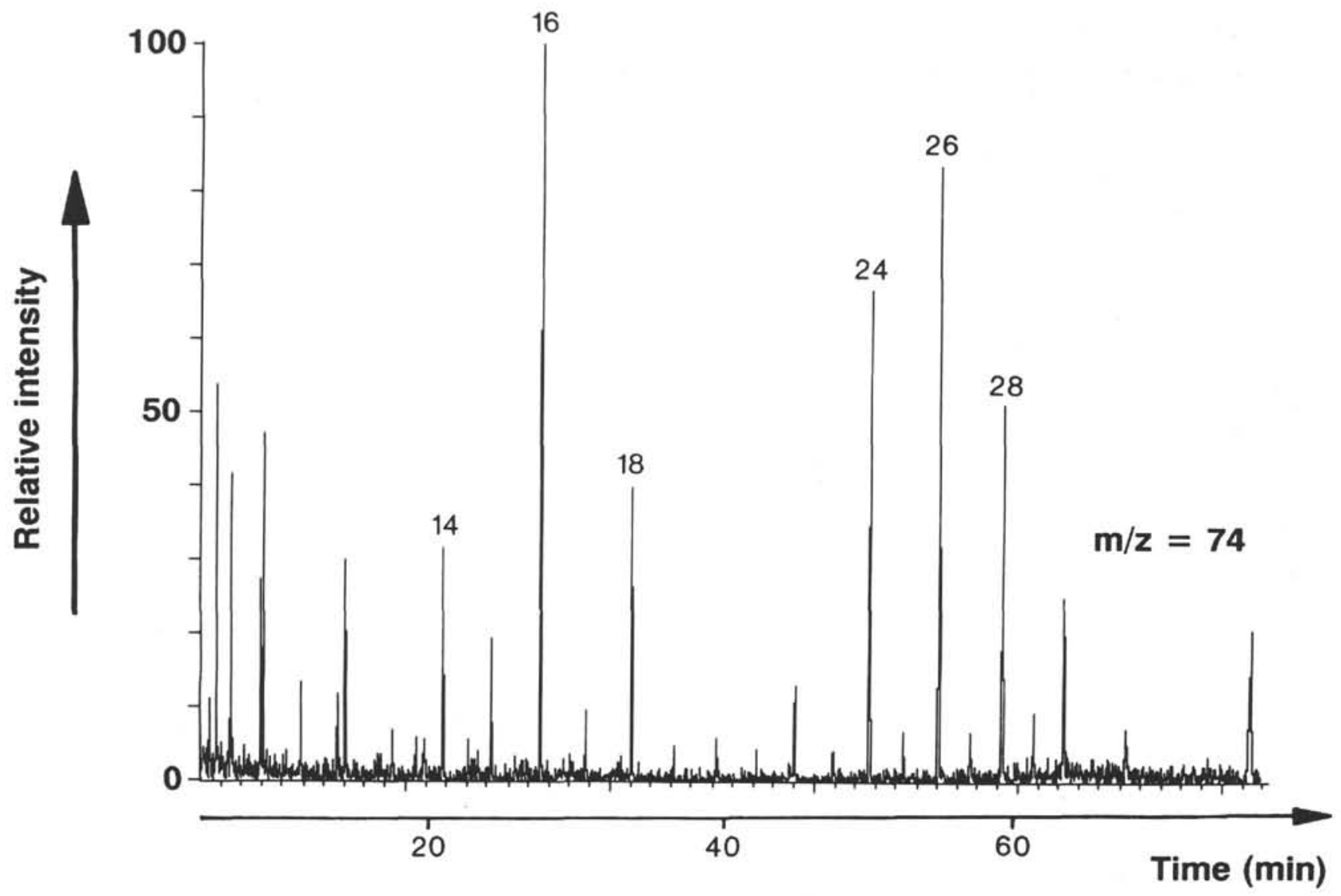

Figure 5. M/z = 74 fragmentogram of a derivatized total extract from Oki Ridge (Site 798), depth 201.3 mbsf. Carbon numbers of linear carboxylic acids are plotted on top of peaks. 


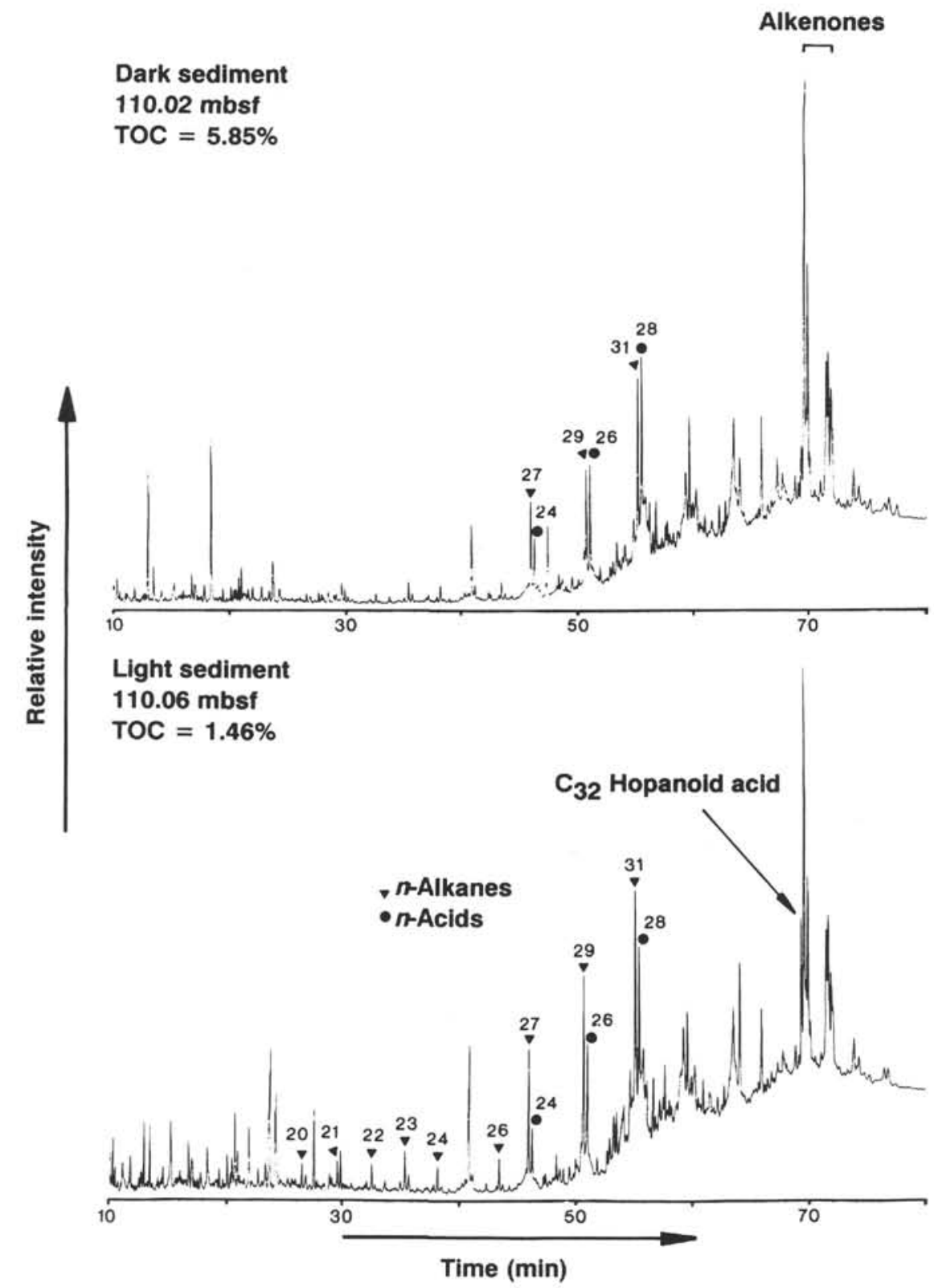

Figure 6. Gas chromatograms of derivatized total extracts from Kita-Yamato Trough (Site 799): dark and light sediments. Carbon numbers are plotted on top of peaks. 